\title{
LATE PLEISTOCENE FUEL MANAGEMENT AND HUMAN COLONIZATION OF THE ATACAMA DESERT, NORTHERN CHILE
}

\author{
Delphine Joly, Calogero M. Santoro, Eugenia M. Gayo, Paula C. Ugalde, Ramiro J. March, \\ René Carmona, Dominique Marguerie, and Claudio Latorre
}

\begin{abstract}
Hunter-gatherers collected and used various woody species depending on the landscape, availability of plant communities, and sociocultural considerations. With extensive paleo-wetlands and groundwater-fed oases, the Atacama Desert was interspersed with riparian woodlands that provided vital resources (fuel, water, and game) at the end of the Pleistocene in areas such as the Pampa del Tamarugal (PdT) basin. We use anthracological analyses to determine the fuel management strategies of hunter-gatherer societies in this hyperarid environment and explore whether the "Principle of Least Effort" applies. First, we present the combustion qualities and characteristics of woody taxa from the Atacama and analyze possible exploitation strategies. Second, we use anthracological analyses from Quebrada Maní 12 (QM12), a late Pleistocene archaeological site (dated from 12,750 to 11,530 cal B.P.) located in the PdT basin, to show the prevalence of two woody species that were either freshly collected or gathered (very likely on purpose) from subfossil wood. Our results suggest that fuel selection strategies were based on prior knowledge of the qualities of these woody taxa and how they burned. Thus we conclude that fuel management was part of a number of social and economic decisions that allowed for effective colonization of this region. Furthermore, we stress the need for caution when using charcoal to exclusively date archaeological sites located in desert environments.
\end{abstract}

Las sociedades de cazadores-recolectores del Cono Sur recolectaron y utilizaron diversas especies leñosas dependiendo de las condiciones del paisaje, las comunidades de plantas disponibles y consideraciones socio-culturales. Las cuencas hidrográficas, como Pampa del Tamarugal (PdT) en el Desierto de Atacama, contaban con extensos paleo-humedales y oasis sustentados con aguas subterráneas, intercalados con bosques ribereños que proporcionaron recursos vitales (combustible, agua y caza) hacia finales del Pleistoceno. Este estudio utiliza análisis antracológicos para definir las estrategias empleadas por los grupos de cazadores-recolectores para la gestión del combustible en este ambiente híper árido y explorar si dicho comportamiento social puede ser explicado por el "principio del menor esfuerzo". En primer lugar, se presentan las cualidades y características de quema de los taxones leñosos del Desierto de Atacama y un análisis de sus estrategias de explotación. En segundo lugar, se utilizan los resultados de análisis antracológicos de muestras de carbones y maderas del sitio arqueológico Quebrada Maní 12 (QM12), ubicado en la PdT y asignado al Pleistoceno tardío (datado entre 12.750 y 11.530

\footnotetext{
Delphine Joly — Laboratorio de Arqueología y Paleoambiente, Instituto de Alta Investigación, Universidad de Tarapacá, Antofagasta 1520 Arica 100236, Chile. Centro de Investigaciones del Hombre en el Desierto, Avenida General Velásquez 1775, Edificio CIHDE, Arica, Chile (delphine.joly@yahoo.fr)

Calogero M. Santoro — Laboratorio de Arqueología y Paleoambiente, Instituto de Alta Investigación, Universidad de Tarapacá, Arica, Chile (calogero_santoro@yahoo.com)

Eugenia M. Gayo $\square$ Center for Climate and Resilience Research (CR)2, Facultad de Ciencias Naturales y Oceanográficas, Universidad de Concepción, Concepción, Chile (emgayo@uc.cl)

Paula C. Ugalde Centro de Investigaciones del Hombre en el Desierto, Laboratorio de Arqueología y Paleoambiente, Instituto de Alta Investigación, Universidad de Tarapacá, Arica, Chile (arqueo.paulaugalde@gmail.com)

Ramiro J. March — CREAAH, UMR 6566 du CNRS Université de Rennes 1, Rennes Cedex, France (ramiro.march@univ-rennes1.fr)

René Carmona $\square$ Departamento de Ingeniería en Maderas y sus Biomateriales, Facultad de Ciencias Forestales y de la Conservación de la Naturaleza (FCN), Universidad de Chile, Santiago, Chile (recarmon@uchile.cl)

Dominique Marguerie — CNRS, ECOBIO, UMR 6553, Université de Rennes 1. Rennes Cedex, France (dominique.marguerie@univ-rennes1.fr)

Claudio Latorre Departamento de Ecología, Pontificia Universidad Católica de Chile. Institute of Ecology \& Biodiversity (IEB), Santiago, Chile (clatorre@bio.puc.cl)
}

Latin American Antiquity 28(1), 2017, pp. 144-160

Copyright @ 2017 by the Society for American Archaeology doi:10.1017/laq.2016.8 
cal a.P.). Estos muestran un predominio de dos especies leñosas recogidas como madera fresca ocolectadas, posiblemente en forma intencional, como "madera vieja". Los resultados revelan que las estrategias de selección del material para la combustión requirieron de un conocimiento previo acerca de cómo se quemaban los taxones leñosos. Consecuentemente, se concluye que la gestión del combustible formó parte de las decisiones sociales y económicas que permitieron una colonización efectiva de esta región. Finalmente, se señala la necesidad de cautela a la hora de interpretar las cronologías arqueológicas basadas exclusivamente en dataciones sobre carbón en sitios ubicados en desiertos.

\section{Fuel Management and Colonization of the} Atacama Desert

$\mathrm{F}$ lollowing the domestication of fire, wood became the main source of thermal energy for prehistoric humans. Wood as a raw material has been a key limiting factor in human adaptation because it affects several basic activities such as cooking, heating, illumination, defense, land-use changes, and so on. The study of charcoal, combustion remains, and other wood management practices provides a unique opportunity to expand our knowledge of fuel use and evolution over time and as a consequence of environmental change. Such archaeobotanical studies further our insight into the dynamics of social processes and the relationship between societies and environments (e.g., Piqué i Huerta 1999; Seijo et al. 2016).

Scientists use traditional, experimental, and analytical anthracological methods, as well as ethnoarchaeological approaches, to explore, understand, and explain the social management of wood (Dufraisse 2012; Henry et al. 2009; Joly et al. 2009; March 1992; Marconetto 2010; Scheel-Ybert and Dias 2007; Théry-Parisot and Henry 2012). The taxonomic identification of those species used as fuel can provide further data for local and regional paleoenvironmental reconstructions. Indeed, this was the emphasis of the earliest anthracological studies (BazileRobert 1982; Chabal 1992; Marguerie and Hunot 2007; Thiébault 1989; Vernet 1973).

Reconstructing wood management practices from the archaeological charcoal record is a significant multidisciplinary challenge. To address this relationship, we show how anthracological analyses based on fuel properties and exploratory experimentation (sensu March et al. 2012) in the hyperarid environment of the Atacama Desert can be used to define fuel exploitation strategies among hunter-gatherer groups that inhabited this area during the late Pleistocene (ca. 13,000-
10,000 B.P.). We hope to shed light on the diverse strategies that hunter-gatherers used for this purpose, including the Principle of Least Effort.

We studied charcoal and wood samples from the archaeological site Quebrada Maní 12 (QM12; Figure 1), located in the Pampa del Tamarugal $\left(\sim 21^{\circ} \mathrm{S}, \mathrm{PdT}\right)$, a large inland basin located in the Atacama Desert. This area, defined as extreme, is characterized by its hyperaridity, which has remained stable since the late Neogene (Jordan et al. 2014) due to the predominance of high evaporation rates and the absence of local rainfall $(<1 \mathrm{~mm} /$ year; Dirección General de Agua 2007). Vegetation is restricted to a discrete oasis where underground and surface water resources are discharged.

QM12 is one of the first known human settlements in the region (12,750-11,530 cal B.P.; Supplemental Table 1); it emerged at a time when substantial local freshwater and woody vegetation existed. These local paleoenvironmental conditions were driven by greatly increased precipitation water budgets in the high Andes during the so-called Central Andean Pluvial Event (CAPE). This led to elevated water tables and perennial river flow throughout the PdT. The resulting oases of riparian vegetation may have played a key role in the dispersion of the first inhabitants of this extreme environment and likely facilitated the initial colonization of western South America (Gayo et al. 2012; Latorre et al. 2013; Nester et al. 2007; Santoro et al. 2011).

Like any population entering a new territory, the first inhabitants of the PdT faced the problem of discovering and managing resources for their survival and social reproduction. This research aims to understand how fuel was managed in such an extreme environment. Consequently, our research question was defined as follows: Was the fuel management of the first hunter-gatherer 


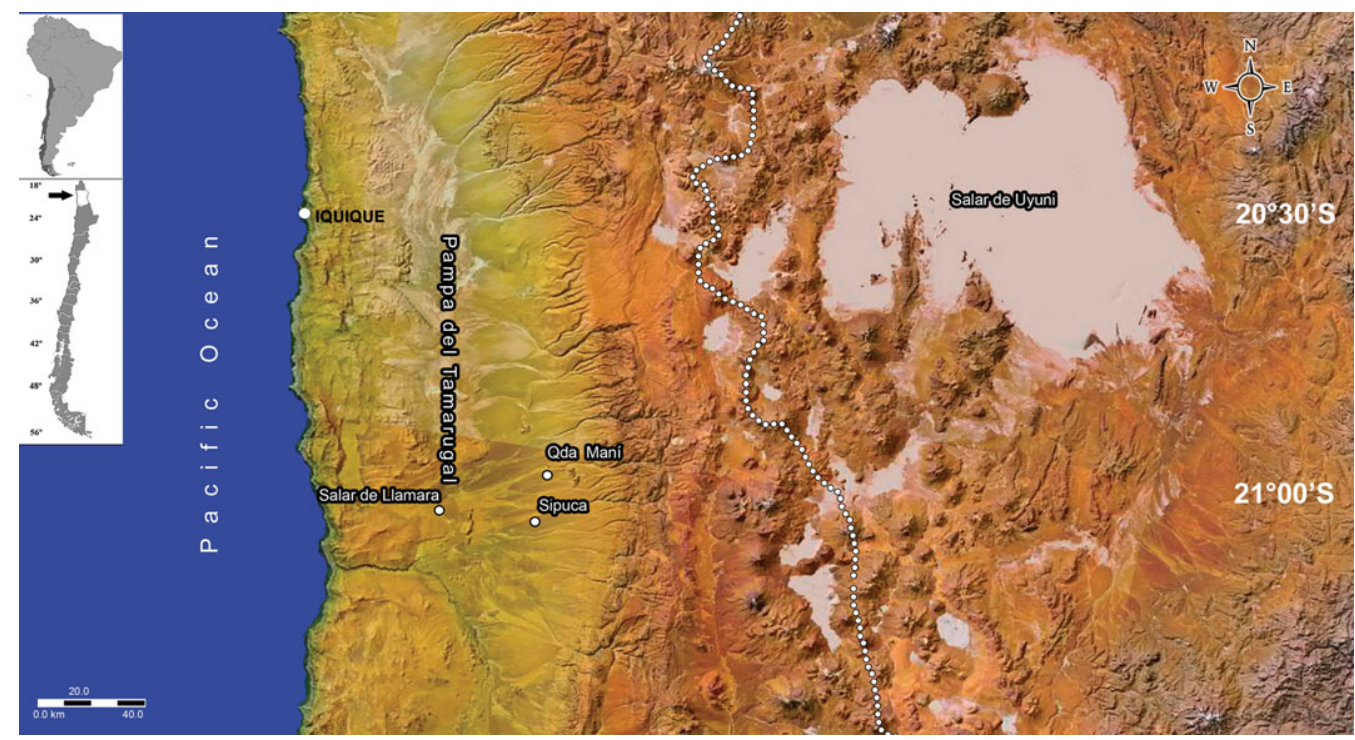

Figure 1. Study area in Pampa de Tamarugal basin showing locations (Quebradas Maní and Sipuca, and Salar de Llamara) of collection of fossil and modern wood samples. (Color online)

inhabitants of the Atacama Desert driven by local environmental conditions?

As a general hypothesis, we propose that these groups, living in an extreme environment with low diversity and fuel availability - and despite the presence of oases - followed the "Principle of Least Effort" (PLE) as defined by Shackleton and Prins (1992). This involved collecting any wood at hand in proportion to its occurrence. If this was the case, anthracological analysis should reveal a broad representation of woody species (trees and shrubs) in terms of taxonomical composition. Otherwise, taxa selection should be evident, indicating that the hunter-gatherer groups selected the best fuel wood for their activities from an abundance of woody resources. In this case, PLE would not apply and choice of fuel wood was likely driven by cultural requirements.

To answer our research questions, we followed two procedures to understand and define raw material exploitation strategies for combustion, according to availability and variability of woody taxa: (1) an anatomical and taxonomic characterization of charcoal remains from the QM12 site, and (2) an experimental study of the physical properties and combustion behavior of native wood samples from the Atacama Desert in different states of preservation to determine their potential as sources of fuel. Our final goal was to show that anthracological analyses are key for understanding fuel management and its relationship to the behavior and adaptability of the first inhabitants of the Atacama Desert.

\section{Vegetation and Climate}

The PdT is an extensive endorheic basin that spans from the Longitudinal Valley (Intermediate Depression) into the Andean piedmont of northern Chile $\left(19^{\circ} 17^{\prime}-21^{\circ} 30^{\prime} \mathrm{S}\right.$; Figure 1). Elevations range from 1,000 to 1,600 masl (Japan International Cooperation Agency 1995). Hyperarid conditions in the PdT date back to the Neogene (12 $\pm 1 \mathrm{Ma}$; Jordan et al. 2014) and are characterized by high evaporation ( $>2,000 \mathrm{~mm} /$ year) and an almost complete absence of local rainfall $(<1$ $\mathrm{mm} /$ year; DGA 2007). Vegetation is restricted to distinct oases formed by groundwater discharge that sustain patchy phreatic-halophytic ecosystems with low species diversity. Further to the north $\left(19^{\circ} 17^{\prime}-21^{\circ} \mathrm{S}\right)$, perennial streams occur along quebradas (ravines or deeply incised canyons). There, emergent groundwater tables along the valley floors provide enough moisture for riparian forests to exist alongside a large number of endemic and native taxa, including 
several species of woody taxa such as Escallonia angustifolia, Baccharis spp, Myrica pavonis, $S$. molle, Geoffroea decorticans, Prosopis alba, and P. tamarugo (Gajardo 1994; Gutierrez et al. 1998; Luebert 2004; Villagrán et al. 1999).

Only small and intermittent streams occur in the southern area of the PdT $\left(21^{\circ}-21^{\circ} 30^{\prime \prime} \mathrm{S}\right)$, including Quebrada Maní, Quebrada Sipuca (Figure 1; Gayo et al. 2012; Nester et al. 2007), and the Salar de Llamara (a salt flat located $\sim 20 \mathrm{~km}$ southeast from the QM12 site; Figure 1). Except for occasional flash floods and mudflows (Houston 2001), these quebradas lack perennial water sources and are almost devoid of vegetation.

The PdT experienced major ecological and hydrological transformations triggered by large positive hydrological anomalies in the adjacent highlands (Gayo et al. 2012; Nester et al. 2007; Workman 2012). The CAPE event involved two main phases dating back to $17,500-14,200 \mathrm{cal}$ B.P. and 13,800-9,700 cal B.P. (Latorre et al. 2006; Placzek et al. 2009). Two pulses of riparian vegetation growth have been documented in Quebrada Maní (17,200-16,100 cal B.P. and $13,400-11,400$ cal B.P.) that are coeval with both CAPE stages (Gayo et al. 2012). By the second CAPE phase a large wetland had formed in Quebrada Maní (ca. 11,200-9,500 cal B.P.; Workman 2012).

\section{Materials and Methods}

The studied archaeological site, QM12, lies at the head of the alluvial fan of Quebrada Maní $(1,240$ masl, $\left.\sim 21^{\circ} \mathrm{S}\right)$ on an erosional remnant $(\sim 1.6$ $\mathrm{km}^{2}$ ) of the Upper Miocene alluvial (T1) terrace (Latorre et al. 2013). The surface is composed of desert pavement, a distinctive trait of arid environments that is typically formed by a layer of thermally fractured clasts of variable sizes and kinds (surficial archaeological layer). The pavement also contains multiple lithics interspersed among the natural clasts. Lithic artifacts include bifaces, bifacial trimming flakes, and debitage, in different stages of manufacture and made out of either local (i.e., basalt) or allochthonous raw materials (high-quality siliceous rocks). Projectile points, morphologically attributable to the late Pleistocene epoch, are common at the surface. Artifacts from later periods are very scarce (two pottery sherds within an area of $1.6 \mathrm{~km}^{2}$; Latorre et al. 2013).

A loose, very fine matrix, locally known as chusca (Avyz horizon), occurs underneath the pavement; it is made up of silt, gypsum, and anhydrite, and can include surface clasts (Adelsberger et al. 2013; Ewing et al. 2006; Finstad et al. 2014; McFadden et al. 1987). The thickness of the Avyz is variable and it is often underlain by layers of sand with silt pockets (ca. 4-5 cm), followed by a second pedogenic salt crust of unknown thickness (Byzm soil horizon). This horizon is culturally sterile; small blocks of this salt crust are reworked into the Avyz horizon (Latorre et al. 2013).

An archaeological excavation of $12 \mathrm{~m}^{2}$ (QM12c) was conducted and reached 30-35 $\mathrm{cm}$ in depth (until the Byzm). Five distinct archaeological layers, numbered from top to bottom, contained numerous debitage and extra local raw materials such as Pacific seashells (cf. Concholepas concholepas, cf. Nassarius gayi, and cf. Argobuccinum rude), plant remains, wooden artifacts (a proximal end of an atlatl spear shaft and a possible scraper haft), red pigment, bone remains (including an apparently cut camelid bone fragment), and a camelid coprolite (Latorre et al. 2013). In layer 3 we found an in situ prepared fireplace (F1) containing a large amount of charcoal. Charcoal remains of variable sizes and mass were found throughout the four archaeological layers. Nineteen AMS ${ }^{14} \mathrm{C}$ dates were performed on different types of materials, such as charcoal, plants, wood, feces, and seashells (Supplemental Table 1). These ages indicate that human occupation occurred over a period of approximately 1,000 years, between 12,750 and 11,750 cal B.P., and that this site served as a location for various daily chores: wood, bone, and lithic tool elaboration; hunting; butchering; food preparation; cooking on a spit; and food consumption (Latorre et al. 2013).

The archaeological context and chronology show that the shallow and loose stratigraphic deposit and its extended surface, scattered with artifacts that are affected by vertical and horizontal migration, was inhabited for almost a millennium at the end of the Pleistocene. This was part of a continental-scale human 
colonization that was taking place at the time in South America. Thus the people that recurrently occupied this space made permanent features, such as the prepared fireplace dug into the hard crust of caliche. The excavated artifacts show that they were skilled lithic knappers and hunters, knowledgeable about plant gathering and other resources. An obsidian flake and artifacts made from shells indicate that these people had access to coastal and highland resources. This implies that they knew how to obtain resources from those ecosystems, or that they maintained exchange interactions with other groups outside the PdT.

One of the interesting features of site QM12 is that four AMS dates on charcoal were anomalously too old (ranging between 16,800 to 14,400 cal B.P.; Supplemental Table 1). Such early dates could result from the use of old or subfossil wood as a source of combustion material (i.e., inbuilt ages). Moreover, several dates are stratigraphically inverted, most likely caused by activities carried out by hunter-gatherers in the campsite, post-depositional processes, or the use of old wood as fuel (subfossil wood that can remain in the landscape for several millennia; Latorre et al. 2013).

\section{Anthracological Analyses}

To determine archaeological charcoal characteristics, we used several methods and materials. First, we created a charcoal reference collection from fresh wood from the modern native woody taxa of the Atacama Desert for the purpose of taxonomic identifications. Key steps involved: (1) Collecting samples of 50 taxa along elevational transects carried out in the Arica and Parinacota Region (17-18 $\mathrm{S}$ and $0-4,500$ masl) and in the Salar de Atacama ( $22^{\circ} 30^{\prime} \mathrm{S}$ and 2,400-3,400 masl). Taxonomic identifications were conducted at the Botany Department Herbarium of the Universidad de Concepción; (2) Preparation of comparative anthracological samples through carbonization of wood fragments from each of the 50 taxa; and (3) Definition of anatomical features of charcoal and wood samples based on observation under an episcopic microscope (Olympus BX41M, magnification 100X, 200X, and 500X) on three anatomical planes-transverse, radial, and tangential (Figure 2 and Supplemental Table 2).

Next, we collected 33 samples of unburned, subfossil timber from the latest Pleistocene terraces of Quebrada Maní (11 samples), Quebrada Sipuca (21 samples), and Salar de Llamara (1 sample; Figure 3 and Table 1). They were identified as above and we characterized their specific microscopic alterations.

Finally, we determined the taxa according to the reference collection and observed the degree of alteration of twenty sample batches of archaeological charcoal from the stratigraphic layer of QM12, focusing on the prepared fireplace. Charcoal samples were obtained by flotation in the laboratory to recover all possible sizes. Over 200 charcoals from each stratigraphic level of QM12 were studied to ensure that the samples were representative. A total of 1,810 archaeological charcoals were observed under the three anatomical planes to determine the taxa. The degree of alteration of archaeological charcoals was defined by using an ordinal scale of criteria observable under the microscope. This included the following properties: structure alteration (deformation, radial and tangential cracks, molten areas, vitrification), brightness, and hardness. Based on the degree of alteration, four levels of combustion were established that do not necessarily correspond to the duration or heat intensity at the time of burning (Figure 4):

Level 0: Partially burned charcoal.

Level 1: Soft charcoal; dull; deformations and cracks are few or absent. Taxonomic identity is easily established.

Level 2: Shiny charcoal with cracks and some deformities; hard, but can be cut. Taxonomic identity can usually be established.

Level 3: Shiny charcoal; some samples have signs of vitrification; hardness ranges from friable to extremely hard. The extent of cracking or deformation can make taxonomic identification hard to establish.

We also observed features not directly linked to combustion such as fungus action, 

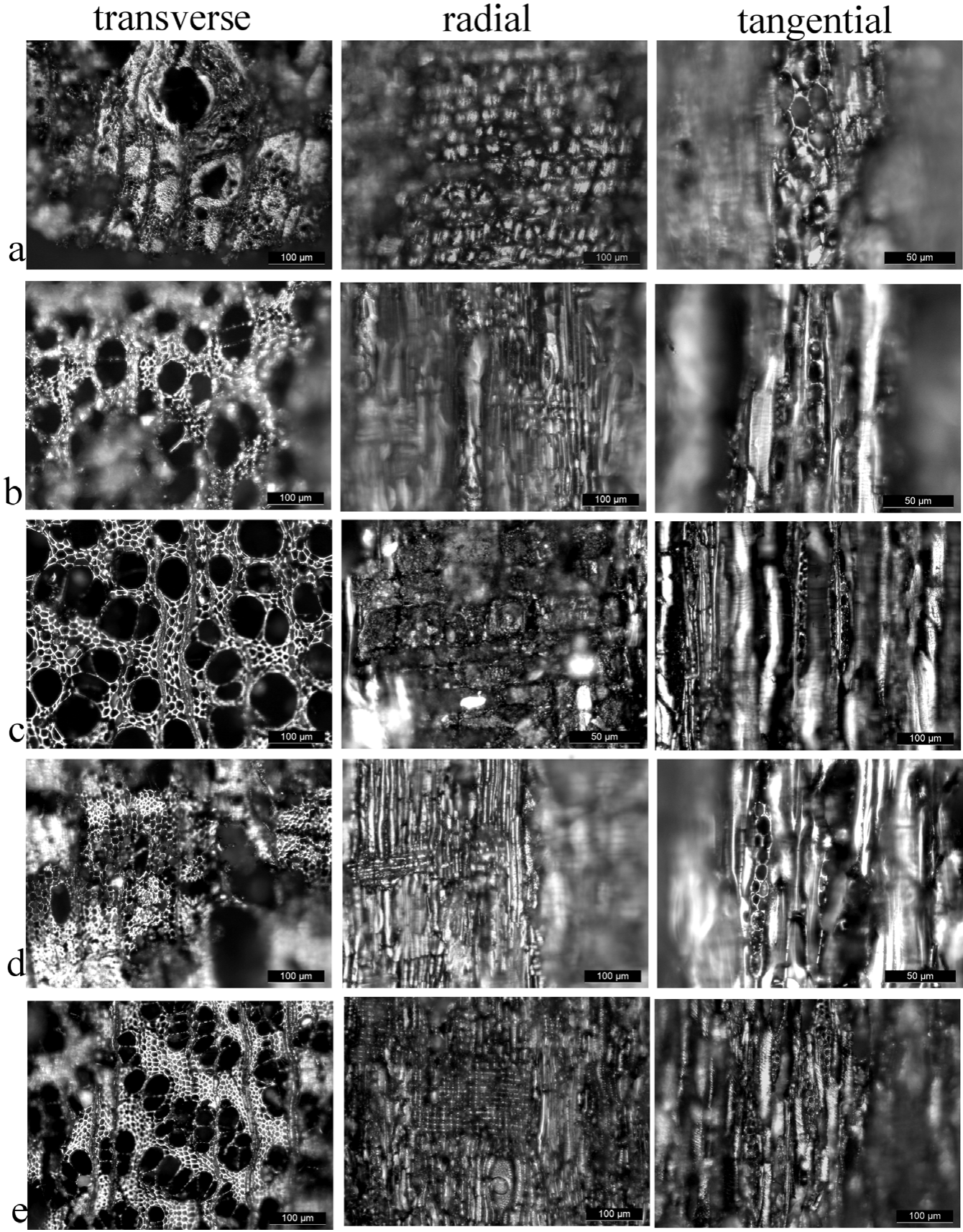

Figure 2. Transverse, radial, and tangential anatomical cuts of identified taxa: (a) Caesalpinia aphylla, (b) Escallonia angustifolia, (c) Myrica pavonis, (d) Prosopis tamarugo, and (e) Schinus molle.

xylophagous galleries, and tyloses on archaeological and subfossil wood, adding information about environment and the state of the wood. Tyloses are outgrowths of parenchymal cells through pits in the vessel walls that either completely or partially close the vessels (Bakour 2003; Carlquist 2001; Nocus 2014; Schweingruber 1990; Schweingruber et al. 2006, 2011; 


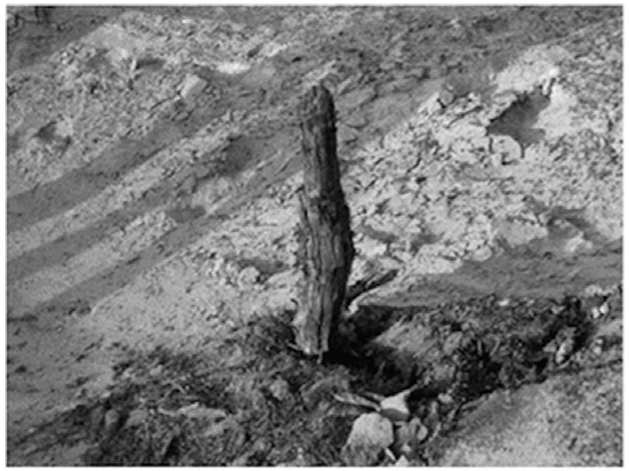

a

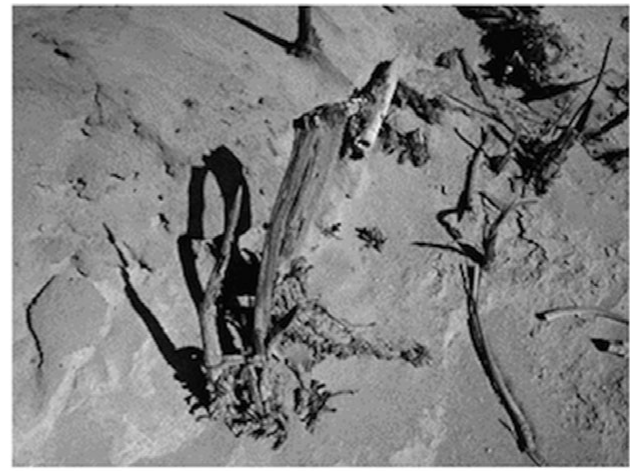

b

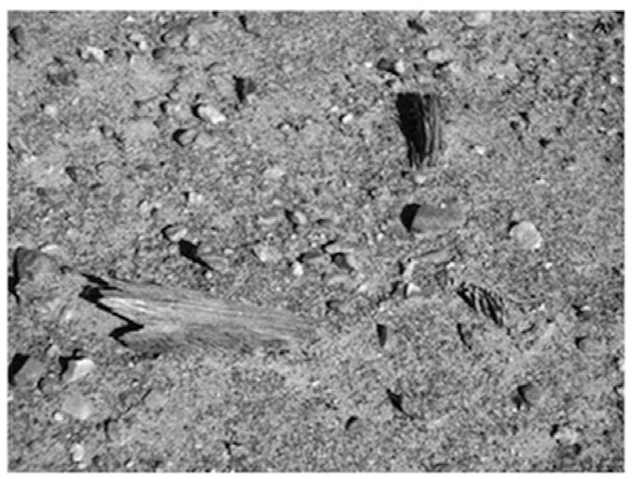

C

Figure 3. In situ subfossil wood preserved on the surface of the Pampa del Tamarugal: (a) unidentified wood from Quebrada Maní, (b) Schinus molle, at Quebrada Sipuca, and (c) unidentified wood Salar de Llamara.

Table 1. Identified and Unidentified Taxa from Subfossil Wood Samples.

\begin{tabular}{lc}
\hline Taxa & Sample number \\
\hline Prosopis sp. & 7 \\
S. molle & 6 \\
C. aphylla & 5 \\
E. angustifolia & 3 \\
cf. Prosopis sp. & 1 \\
Unidentified specimens & 11 \\
Total & $\mathbf{3 3}$ \\
\hline
\end{tabular}

Sun et al. 2006). These may appear in the heartwood (the hardened, older core that stops receiving irrigation while the specimen is still alive) of some genera. Such features may be also related to tree size, age, and degree of lignification (Schweingruber 1990; Schweingruber et al. 2006; Sun et al. 2006). For instance, in oak species (Quercus spp.), tylosis occurs in trees over 15 years old (Bakour 2003) or those affected by traumas caused by various agents such as fungus, bacteria, and hydric stress (Carlquist 2001; Schweingruber 1990; Schweingruber et al. 2006, 2011; Sun et al. 2006).

\section{Combustion Properties Analyses of Modern and Subfossil Woody Taxa}

Eight wood samples were selected for combustion properties analyses (moisture, calorific value, ash content, and density). These consisted of four samples of modern trees and shrubs (M. pavonis, P. alba, S. molle, and Tessaria absinthioides) and four subfossil samples $(C$. aphylla, Prosopis sp., S. molle, and an undetermined taxon) (Table 2). From each of these specimens, we sampled branches of $0.5-2 \mathrm{~cm}$ 


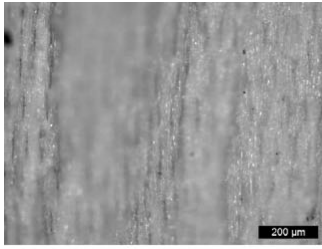

a

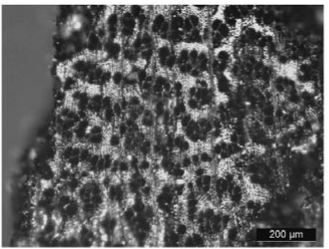

b

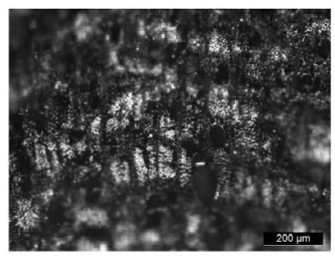

C

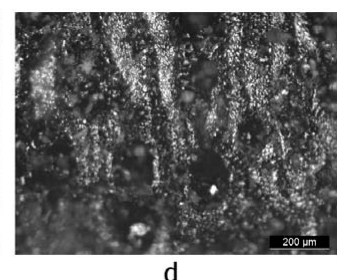

d

Figure 4. Level of alteration in four archaeological charcoal samples: (a) level 0, (b) level 1, (c) level 2, and (d) level 3. Image (a) corresponds to a radial cut. Images $(b, c, d)$ show transverse cuts.

Table 2. Fuel Properties from Modern and Subfossil Wood Samples. (QM: Quebrada Maní; QS: Quebrada Sipuca; SLL: Salar de Llamara.)

\begin{tabular}{lcccccccc}
\hline & & & & Actual \\
Sample & Taxon & Type & $\begin{array}{c}\text { CH\% } \\
\text { average }\end{array}$ & $\begin{array}{c}\text { Moisture } \\
(\% \text { b.s. })\end{array}$ & $\begin{array}{c}\text { Basic } \\
\left(\mathrm{g} / \mathrm{cm}^{3}\right)\end{array}$ & $\begin{array}{c}\text { Inferior calorific } \\
\left(\mathrm{g} / \mathrm{cm}^{3}\right)\end{array}$ & $\begin{array}{c}\text { value }(\mathrm{PCI}) \\
(\mathrm{Kcal} / \mathrm{Kg})\end{array}$ & $\begin{array}{c}\text { Ashes } \\
(\% \text { b.s. })\end{array}$ \\
\hline MR1 & M. pavonis & tree & - & 10.9 & 0.61 & & 4,422 & 2.4 \\
MR2 & P. alba & tree & - & 10.1 & 0.8 & & 4,170 & 7.0 \\
MR3 & S. molle & tree & 150.7 & 13.25 & 1.07 & 0.49 & 4,159 & 5.4 \\
MR4 & T. absinthioides & bush & 109.62 & 10.69 & 0.96 & 0.57 & 4,129 & 3.0 \\
QM65 & C. aphylla & bush & - & 7.3 & 1.15 & & 4,510 & 6.1 \\
QM70 & Prosopis sp. & tree & - & 7.2 & 0.7 & & 4,063 & 7.7 \\
QS21 & S. molle & tree & - & 8.7 & 0.83 & & 4,169 & 7.4 \\
SLL13 & Unidentified & n/i & - & 10 & 1.21 & & 4,262 & 5.7 \\
\hline
\end{tabular}

diameter that were then broken apart for the following measurements:

(1) Moisture content (HC) based on the Chilean standard (ChS 176/1; gravimetric method in oven), expressed as a percentage in dry base in stove (anhydrous).

(2) Lower calorific value measured with a Parr 6200 calorimeter, following European technical specifications (CEN/TS 14918 2005). Measurements were taken on the $\mathrm{HC}$ of the sample at the moment of determination.

(3) Ash content, according to American Society and Testing Materials standards (ASTM 1755-01, 2008), expressed as percentage of the original dry mass.

(4) Current or trial density or correlation between $\mathrm{HC}$ mass and volume at the moment of determination ( $\mathrm{ChN} 176 / 2)$ (Cisternas 1994). In the case of fresh wood samples, basic density was also determined. This parameter describes the correlation between dry mass (anhydrous) and green volume (humid).
Table 3. Subfossil Wood Samples Used for Experimental Analysis. (QM: Quebrada Maní; QS: Quebrada Sipuca; SLL: Salar de Llamara.)

\begin{tabular}{lccc}
\hline $\begin{array}{l}\text { Sample } \\
\text { number }\end{array}$ & $\begin{array}{c}\text { Sample } \\
\text { location }\end{array}$ & Taxa & $\begin{array}{c}\text { Initial } \\
\text { weight (g) }\end{array}$ \\
\hline 1 & QM65 & C. aphylla & 300 \\
2 & QM70 & Prosopis sp. & 300 \\
3 & QS22 & S. molle & 200 \\
4 & QS21 & S. molle & 300 \\
5 & QS13 & C. aphylla & 300 \\
6 & SLL13 & Unidentified & 300 \\
\hline
\end{tabular}

\section{Observation of Experimental Combustion of Subfossil Wood}

We observed the combustion properties of subfossil wood collected in the Atacama Desert (Table 3) and evaluated its feasibility as a fuel source and combustion temperatures by performing six experiments. In each of these experiments, ca. $300 \mathrm{~g}$ of wood was burned outdoors on a concrete table. No additional wood was added during the combustion. Temperatures were measured with a K-type thermocouple, placed in the middle of the woodpile during combustion. 

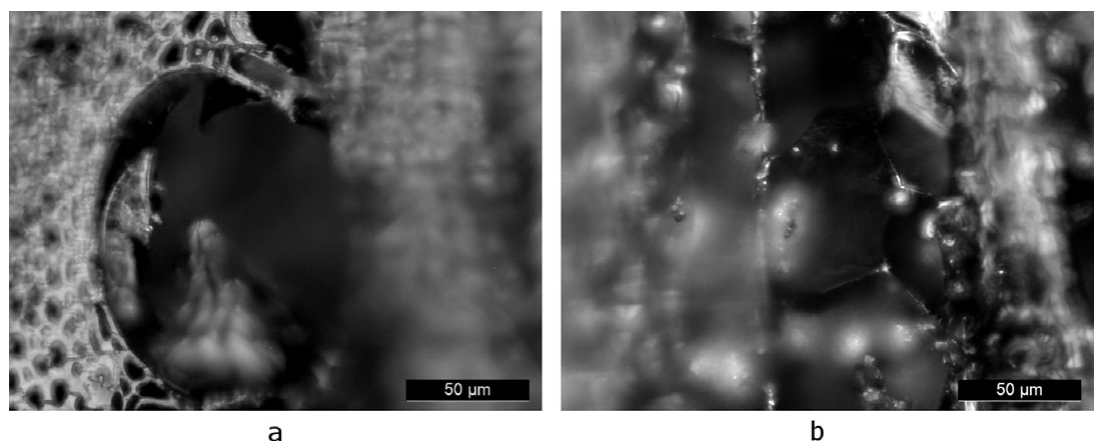

Figure 5. Example of tylosis in Schinus molle: (a) transverse cut, and (b) radial cut.

Afterward, combustion duration was verified and final weight of charcoal and ash was measured.

\section{Results}

Microscopic Observations and Anthrocological Analyses

In general, subfossil wood and archaeological charcoals present tissues with highly deteriorated cellular structures. Pores appear deformed in cross section, which certainly hindered microscope observations. For radial and tangential sections, the observation of small elements (e.g., pits and spiral thickening) was difficult. Several samples presented xylophagous insect galleries. We detected tyloses in some samples assigned to S. molle and Prosopis sp. (Figure 5).

Despite the poor preservation of subfossil wood, taxonomic assignment to genus or species was possible for two-thirds of the 33 samples. Overall taxonomic diversity is low, represented by only four taxa, particularly by trees such as Prosopis sp., S. molle, and E. angustifolia; C. aphylla, a woody shrub, was also identified (Table 1). The unidentified species in this table include $P$. tamarugo and P. alba, which we were not able to distinguish because of very similar anatomical features.

In contrast, the resolution for taxonomical determinations of archaeological charcoals, inferred from the description of the anatomical sections of various identified species presented in Supplemental Table 2, was comparatively higher (97 percent; $n=1,756$; Figures 2 and $6)$. The taxonomic diversity was low (three taxa) and dominated by two species identified as the trees $S$. molle and M. pavonis (which no longer grows in Quebrada Maní); both are found in every level and in the prepared fireplace (F1) at QM12 (Figure 6). Charcoal from S. molle is very abundant in archaeological levels 1 through 4 and in F1, and ranges from 78.5 to 95 percent of the total sample. M. pavonis is less abundant and ranges from 3 to 14 percent of the total sample. This pattern reverses in level 5, as M. pavonis is much more abundant (94 percent) than $S$. molle (2.5 percent). Carbonized remains of a single unidentified dicotyledonous species ( 0.7 percent $)$ were found in levels 3-5. Unidentified fragments (burned seeds, stems) of monocotyledon plants were found in low proportions in levels 1-4 and in the fireplace ( 0.5 percent).

The degree of alteration of the anatomical structure of archaeological charcoal varies among species. S. molle presents the highest levels of alteration ( 2 and 3 ), and includes elevated numbers of tyloses. This characteristic was not observed in the other specimens of the sample. M. pavonis charcoals present the lowest levels of alteration (1; Figure 7). Only 30 percent of the samples show radial cracks. Vitrified charcoals were absent, as were pith bark or insect galleries.

\section{Dating Identified Charcoal}

Two samples of charcoal taxonomically identified as M. pavonis and S. molle from stratigraphic level 5 in QM12 were selected for radiocarbon dating (Supplemental Table 1). These ages reveal that the $S$. molle charcoal $(15,700$ years B.P.; UCIAMS-145256) is significantly older than 

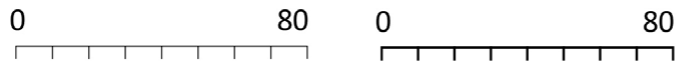

$5 \%$
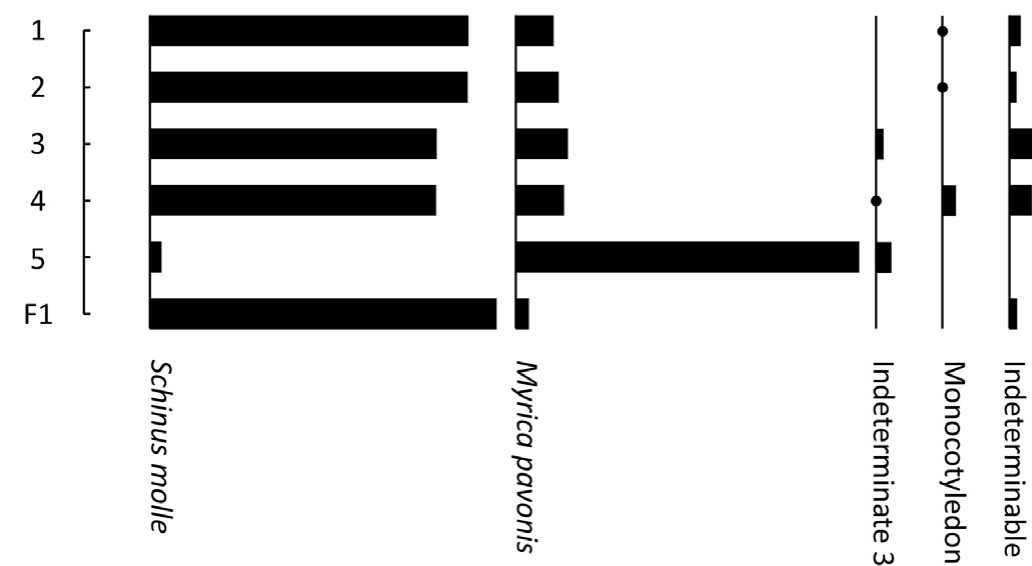

Figure 6. Anthracological diagram of identified taxa of charcoal samples from the five archaeological levels of QM12, numbered from top to bottom, and the prepared fireplace $(F 1)$. Values are in percentages. Indeterminate 3 corresponds to a single dicotyledonous species $(0.7$ percent). Indeterminable corresponds to undetermined fragments.

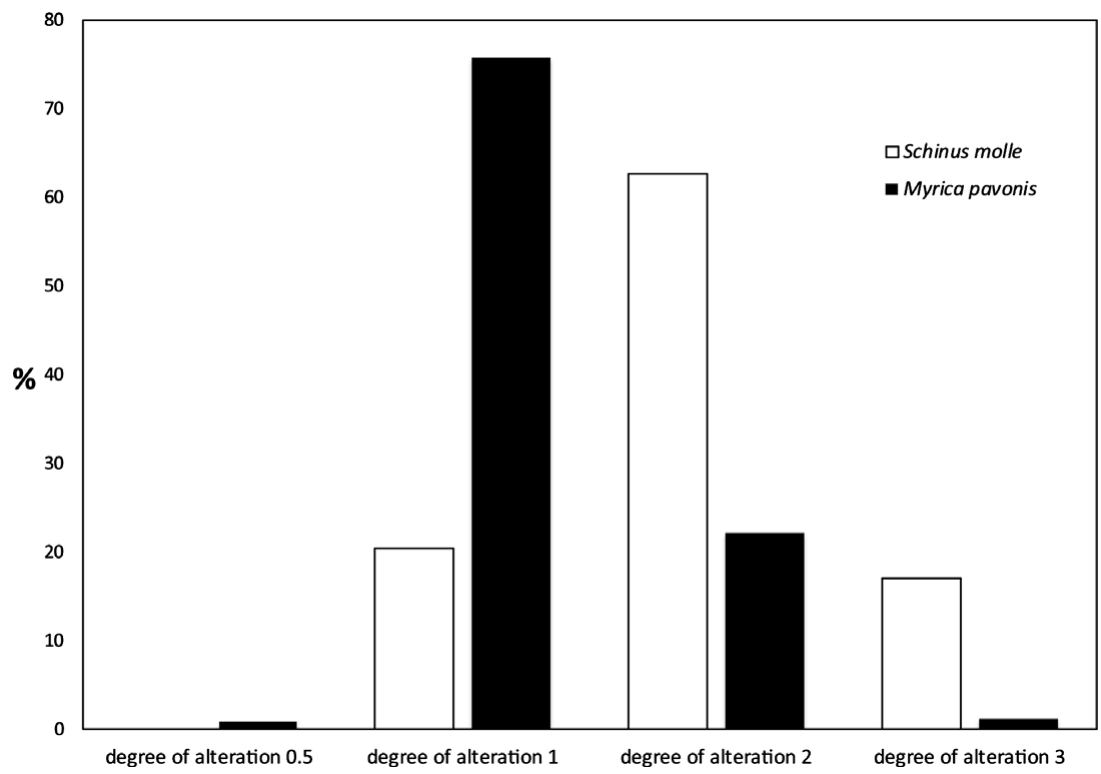

Figure 7. Degree of alteration observed in anatomical structures of the identified species in the archaeological charcoal samples.

the M. pavonis charcoal (12,200 years B.P.; UCIAMS-145255).

\section{Combustion Properties of Modern and}

Subfossil Woods

Excluding modern samples of $S$. molle (MR3; Table 2) and T. absinthioides (MR4), most samples were collected dry. In general, moisture percentage of dry logs ranges from 10.9 to 7.05 percent (Table 2). These values are close to the content of equilibrium moisture for wood in the study area, characterized by a low relative humidity $(\sim 10$ percent $)$ and elevated temperatures (Bluhm et al. 1965). In comparison, subfossil samples of C. aphylla (QM-65), Prosopis sp. (QM-70), and S. molle (QS-21) show the lowest 
moisture levels (7.3-8.7 percent). Only sample SLL-13 (10 percent) shows a moisture level comparable to those seen in modern specimens.

The Lower Calorific Value (LCV) of subfossil wood ranges from 4,063 to $4,510 \mathrm{kcal} / \mathrm{kg}$, within the known range of broad-leaf wood (Senelwa and Sims 1999). More precisely, the LCV for anhydrous wood from deciduous trees has a calculated mean of $4,300 \mathrm{kcal} / \mathrm{kg}$, whereas wood from coniferous trees average $4,600 \mathrm{kcal} / \mathrm{kg}$ (Vautherin 1995).

In general, subfossil wood tends to have higher ash content, which varies from 6.1 to 7.7 percent (Table 2). Excluding P. alba (7.0 percent; Table 2), the percentage values of ash content for recent wood are smaller and range from 5.4 to 2.4 percent. Even though the amount of ash is different for subfossil and modern wood samples, the values fall in the upper ranges for wood obtained from desert phreatophytic trees (Habit 1985). It is likely that the reduction of the LCV produced by the presence of high ash content is offset by a higher presence of extractive elements in some of these samples (Prosopis spp.), which are known for having a higher LCV than other wood components (White 1987). Sample density varies between .61 and $1.21 \mathrm{~g} / \mathrm{cm}^{3}$ in modern and subfossil wood.

\section{Combustion Analysis of Subfossil Wood}

The results obtained show that subfossil wood is more difficult to ignite than modern wood. Ignition times ranged from 5 to 22 minutes ( $\mu$ $=14$ minutes; Supplemental Table 3). These samples produced flames of short duration, ranging from 0 to 22 minutes ( $\mu=12$ minutes), that were slowly extinguished, forming hot coals, and then were completely reduced to ashes. The time from when the flames were extinguished until the temperature started to drop ranged from 21 minutes (experiment number 3) to $86 \mathrm{~min}$ utes, with a mean of 53 minutes of combustion time without flame. During combustion, temperatures ranged from $350^{\circ}$ to $500^{\circ} \mathrm{C}$ (Figure 8). An exceptionally high temperature of $768^{\circ} \mathrm{C}$ was recorded in experiment 2 using Prosopis firewood (Figure 8).

$S$. molle and M. pavonis charcoals show very different levels of alteration. M. pavonis charcoals have few alterations (level 1) and charcoal is easily identified, whereas $S$. molle charcoals are more altered (levels 2 and 3). Although combustion and differential conservation cannot be totally excluded, it is most likely that this degree of alteration preceded the combustion event. The presence of tyloses in large numbers only in $S$. molle charcoal could be due to several factors. The absence of fungus and xylophageous galleries indicate that the $S$. molle wood did not suffer attacks from these organisms. More likely, it was hydric stress (Schweingruber 1990; Schweingruber et al. 2011) that caused tyloses formation in our samples. S. molle is a facultative phreatophyte that grows preferentially in areas that are occasionally flooded along perennial or ephemeral quebradas in the Atacama Desert; it survives drought by obtaining water from unconfined aquifers (Gayo et al. 2012). A lack of flooding or a lowering of the groundwater table could trigger the formation of tyloses in QM12 $S$. molle charcoals as a result of hydric stress.

The other possibility is that the charcoals come from heartwood of trees old enough to form tyloses (Carlquist 2001; Schweingruber et al. 2006, 2011). Heartwood is more resistant to attacks by insects and denser than sapwood; the presence of tyloses makes wood more resistant to decay (Taylor et al. 2002). The abundance of tyloses taken together with the altered structure (degree of alteration 2 and 3) seen in S. molle charcoals suggest that these originated from the combustion of subfossil wood that remained on the landscape from trees that grew in groves, possibly thousands of years before the QM12 site occupation. This would also explain why fresh $S$. molle wood samples we collected in the area surrounding the site do not show any tyloses.

Modern and subfossil wood taxa have different properties but both tend to have good firewood quality. Results from physical-chemical properties analyses of modern and subfossil wood, however, suggest that each category has different qualities. Subfossil wood exhibited lower moisture levels and higher ash percentages. But LCV for these samples is almost the same as modern wood. Density can be influenced by wood moisture, but values can still be compared, since the difference in the moisture content is very small and does not significantly change basic density. Variations in density and moisture 


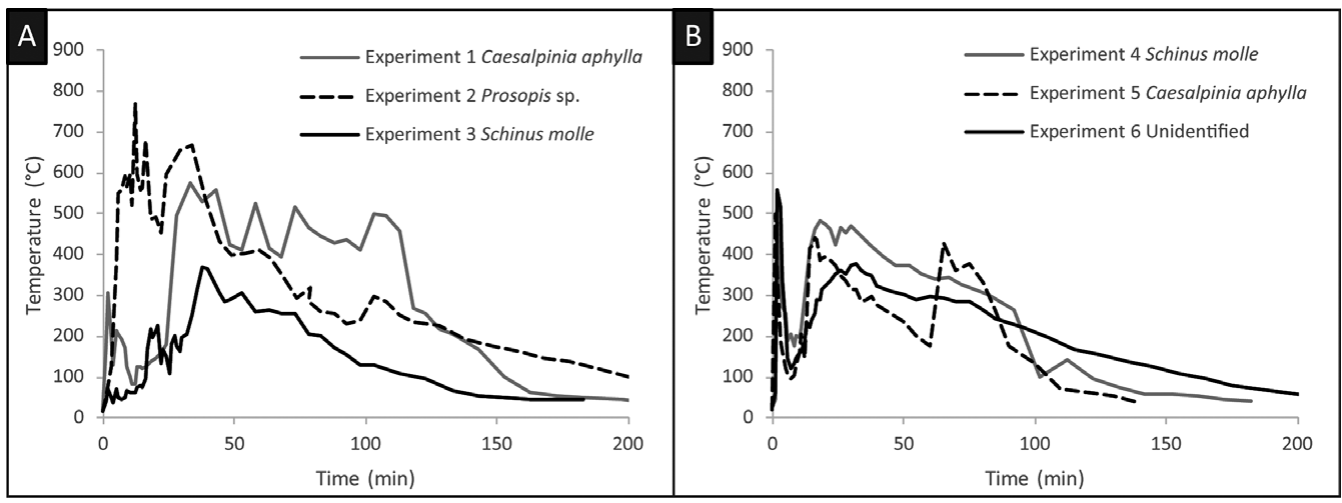

Figure 8. Temperatures $\left(\right.$ in ${ }^{\circ} \mathrm{C}$ ) reached by experimental burning wood samples over time. (See also Supplemental Table 3.)

play a key role in combustion, despite their calorific value. Woods with lower density (less wall in the fibers) and higher moisture levels do not last as long in the fire. Woods with higher density and lower moisture levels, such as the subfossil samples, take longer to burn out and would be considered better firewoods (Kataki and Konwer 2001; Vautherin 1995). Nonetheless, these are also more fire-resistant and take longer to ignite. In contrast, due to their higher moisture level and lower density level, modern woods are easier to ignite but have shorter combustion times.

Both S. molle and M. pavonis are longstemmed and thick-branching trees with wood that exhibits similar physical properties. S. molle is denser than $M$. pavonis but has a higher moisture and ash content, making it less suitable as fuel (Table 2). The two species constituted most of the charcoal we examined. The monocotyledon stems identified in our samples could have been used to light the fire. Small quantities of other species that may have been used for tinder may not have been preserved and therefore cannot be excluded.

\section{Discussion}

The taxonomic richness found in charcoal from the QM12 site shows an unusual pattern of preferential selection toward just two trees, $S$. molle and M. pavonis, even though a broad variety of woody species was available in the PdT. Indeed, Gayo et al. (2012) have shown that several species of trees (Escallonia angustifolia, Myrica pavonis, Schinus molle, Caesalpinia aphylla) and shrubs (Baccharis scandans, Tessaria absinthioides) were present in the Tamarugal basin during the late Quaternary, from 17,000 to 11,000 cal B.P. Furthermore, the archaeological context shows that these people had access to special coastal and highland resources (e.g., shells and obsidian). This means that they could have also imported trade woods from nearby ecosystems but chose not to. Conversely, the few anthracological analyses of hunter-gatherer sites from the higher elevation regions of the central and southern Andes show the opposite. Indeed, a wider taxonomic diversity in charcoals with a general predominance of shrubs has been documented for early Holocene hunter-gatherer camps in the Puna of Argentina (Barberena 2015; Joly 2008; Joly et al. 2009; Rivero 2012; Rodriguez 1999, 2000, 2005). This implies that the first inhabitants of the Atacama Desert were not constrained by the environment and that the PLE hypothesis does not apply in this context. Our results show that main drivers of fuel wood management were cultural and that wood was abundant enough to allow people to select what they considered the best choices.

Our study indicates a selection preference for thicker wood, regardless of its availability (Joly 2008; Joly et al. 2009). The lack of charcoals attributable to a $M$. pavonis in stratigraphic levels 1-4 may have been the result of a preservation bias because of its rapid ignition 
and lower production of charcoals (compared to $S$. molle). We speculate that $M$. pavonis was used as tinder (a role associated with herbaceous materials) to keep the $S$. molle combustion from dying out. Our experimental results indicate that an open fireplace could have been run using only subfossil wood as fuel, but it would have been difficult to ignite, burning flamelessly and without achieving very high temperatures. The choice of $M$. pavonis dry firewood as tinder by the people of QM12 suggests that they had some experimental knowledge and know-how regarding combustible materials. The selection of $S$. molle subfossil firewood over a number of other possibilities may have been motivated by non-excluding factors such as (1) its character as a thick firewood that was useful to stoke the fire without burning out the wood, or (2) its subfossil character of heartwood preservation that gives it extraordinary dryness and density, and the presence of tyloses, which accords a higher calorific value.

This clear selection of subfossil S. molle wood strongly suggests that the QM12 occupants were familiar with its qualities. Indeed, the limited taxa of wood used in combustion at QM12 implies that during the occupation of the QM12 site, there were no changes in wood management, even though there were different raw materials available (i.e., Prosopis sp.).

Our study further implies that ${ }^{14} \mathrm{C}$ dates of early sites like QM12 should be withheld from chronological consideration until it is confirmed that they are not derived from subfossil wood chosen by ancient people. This is a relatively straightforward task when dates are anomalously old but more difficult when the ages are concordant with other materials. Such findings are relevant to most charcoal dates in the northern Atacama Desert, where the hyperarid environment preserves wood very well, as seen in other archaeological records from arid regions (Schiffer 1986). Although the "old wood" issue is not new, any chronology related to cultural processes involving site formation and radiometric dating in arid environments must take into consideration the possible and indeed purposeful selection of subfossil wood for its fuel qualities (Barniak et al. 2013; Kennett et al. 2002; Klusek and Pawelczyk 2014; Kolář et al. 2014; Schiffer
1986). This issue is usually not considered when discussing artifacts introduced into the archaeological chronologies of northern Chile.

\section{Conclusion}

The anthracological methodology applied here in a context of hunter-gatherer societies during the late Pleistocene in the hyperarid Atacama Desert opens a new perspective on combustion resource management in an environment devoid of diverse raw material. Although one would expect the application of the Principle of Least Effort to fuel management at Quebrada Maní 12, the behavior of hunter-gatherers shows that a notable level of organization and decision-making was involved. These decisions were based on experimental technical knowledge regarding the properties of the local woody species. The occupants likely chose dry S. molle wood for combustion because they had discovered its qualities of hardness and density (as a result of heartwood preservation and tylose presence). These subfossil logs could have been found around the domestic activity area on the T1 surface (Latorre et al. 2013). The second element selected for combustion was dry wood from $M$. pavonis trees, which likely grew at the same time when the occupation took place. It is possible that the QM12 people preferred these two woody species to other taxa available in the area because both taxa produce thick firewood that is easy to collect and possesses good combustion qualities. Given the anatomical and physical-chemical features of these woods, their combustion as a whole was a technological solution that allowed huntergatherers to overcome the difficulty of burning S. molle subfossil wood. Adding M. pavonis dry wood to the combustion process would have made ignition and combustion easier (with the help of other tinder). This exploitation pattern of fuel logs differs from what had been observed in other prehispanic societies from the central and southern Andes (Escola et al. 2013; Joly 2008; Joly et al. 2009; Rodriguez 2000).

Experiments and the resulting physicalchemical characterization (calorific value, density, moisture, and ash rates) allowed us to understand the properties of each of the species found at the site. These further complemented the 
taxonomic identifications as well as the anthracological anatomical observations. Such a combination of analytical procedures is key for broadening and complementing our understanding of fuel economy in environmental and chronological contexts of human occupation toward the end of the Pleistocene in the hyperarid core of Atacama. In summary, anthracological analyses represent a key tool for understanding fuel management in extreme environments, such as deserts, where subfossil wood can be found on the surface that might be thousands of years old and was very likely used by prehistoric dwellers. This interesting subject will be the aim of future publications.

Finally, the studies at QM12, the first late Pleistocene archaeological site at the core of the Atacama Desert, opens up the discussion of the processes of human colonization of the western side of the Andes, where coastal and highland camps show clear evidence of human occupation by the end of the Pleistocene. The results have allowed us to better interpret the systemic context of these hunter-gatherer groups, who show environmental experience and a willingness to experiment on the ecosystem of the Atacama Desert. This supports the idea that steady regional processes of human colonization were taking place in South America by the end of the Pleistocene. Thus, local, cultural, and social variation may account for much earlier processes of exploration of the continent and the possibility that more than one migratory route was followed by the earliest South Americans.

Acknowledgments. Main funding for this research was provided by Fondo Nacional de Desarrollo Científico y Tecnológico (FONDECYT) grants \#3120251 (to DJ). It also received the support of \#1120454, (to CMS, CL), \#3130668 (to EMG), and Centro de Investigaciones del Hombre en el Desierto (CIHDE), founded by the Comisión Nacional de Investigación Científica y Tecnológica CONICYT-Regional R14F1008 (to PCU and EMG). We acknowledge ongoing support from Institute of Ecology and Biodiversity (IEB) grants ICM P05-002 and PFB-23 (to CL), the Centro de Ciencia del Clima y la Resiliencia (CR)2 (FONDAP/CONICYT \#15110009 to EMG), the Universidad de Tarapacá, Instituto de Alta Investigación, Laboratorio de Arqueología y Paleoambiente (to CMS, DJ, and PCU), and CONICYT, Programa de Investigación Asociativa (PIA), Proyecto Anillo Código SOC1405 (to CMS, EMG, and CL). We also thank the Herbario Departamento de Botánica, Facultad de Ciencias Naturales y Oceanográficas, Universidad de Concepción),
Departamento de Ingeniería en Maderas y sus Biomateriales, Facultad de Ciencias Forestales de la Conservación de la Naturaleza (Universidad de Chile) and BioArCh, University of York. Final editing of this paper was done through the Coopération Scientifique ECOS-CONICYT grant \#C13H02 (CMS, DJ, EMG, and RJM). All local permissions for archaeological excavations were granted by the Consejo de Monumentos Nacionales ORD. $N^{\circ}$ 4379, October 18, 2012, and the ethnic committee of the Universidad de Tarapacá.

Data Availability Statement. All data are provided in full in the results section of this paper and supplemental materials.

Supplemental Materials. Supplemental materials are linked to the online version of this paper, which is accessible via the SAA member login at https://doi.org/10.1017/laq.2016.8. These include the following tables:

Supplemental Table 1. AMS Radiocarbon Dates on Charcoal and Plant Remains from QM12 Archaeological Site. Dates were calibrated in CALIB 7.0.1 (Stuiver and Reimer, 1993) using the SHCAL13 calibration curve (Hoggs et al. 2013) at 2-sigma level. (*) Indicates dates reported by Latorre et al. (2013). Radiocarbon determinations by UCIAMS are corrected for isotopic fractionation using AMSmeasured delta ${ }^{13} \mathrm{C}$ ratios. $\left({ }^{\sqrt{ }}\right)$ Indicates ages excluded from the occupational chronology of the site.

Supplemental Table 2. Description of Three Anatomical Cuts of Identified Taxa.

Supplemental Table 3. Results of Wood Ignition, Flame and Combustion without Flame Duration, and Temperature Drop in Experiments.

\section{References Cited}

Adelsberger, Katherine A., Jennifer R. Smith, Shannon P. McPherron, Harold L. Dibble, Deborah I. Olszewski, Utsav A. Schurmans, and Laurent Chiotti

2013 Desert Pavement Disturbance and Artifact Taphonomy: A Case Study from the Eastern Libyan Plateau, Egypt. Geoarchaeology 28(2):112-130.

Bakour, Riad

2003 Influence de l'espèce et de la provenance des deux principaux chênes français (Quercus robur L.; Quercus petraea Liebl.) sur la structure anatomique et les propriétés physiques du bois de merrain. Ph.D. dissertation, Sciences of the Universe, École Nationale du Génie Rural, des Eaux et des Forêts (ENGREF) (AgroParisTech), Paris.

Barberena, Ramiro

2015 Cueva Huenul 1 Archaeological Site, Northwestern Patagonia, Argentina: Initial Colonization and MidHolocene Demographic Retraction. Latin American Antiquity 26:304-318.

Barniak, Joanna, Marek Krapiec, and Leszek Jurys

2013 Sub-Fossil Wood from the Rucianka Raised Bog (NE Poland) as an Indicator of the Climatic Changes in the First Millenium BC. Geochronometria 41(1):104110.

Bazile-Robert, Evelyne

1982 Données expérimentales pour l'anthracoanalyse. Etudes Quaternaires Languedociennes 2:19-28. 
Bluhm, Edgar, Ramón Rosende, and Walter G. Kauman 1965 Determinación de la humedad de equilibrio de la madera en todas las zonas climáticas de Chile. Informe Técnico 21. Instituto Forestal, Santiago.

Carlquist, Sherwin

2001 Comparative Wood Anatomy: Systematic, Ecological, and Evolutionary Aspects of Dicotyledon Wood. Springer, Berlin.

Chabal, Lucie

1992 La représentativité paléo-écologique des charbons de bois archéologiques issus du bois de feu. Bulletin de la Société Botanique de France, Actualités Botaniques 139(2/3/4):213-236.

Cisternas, Aldo P.

1994 Conversión de densidades de la madera. Ciencia e Investigación Forestal 8(2):302-315.

DD CEN/TS 14918

2005 Solid Biofuels. Method for the Determination of Calorific Value. British Standards Institution.

Dirección General de Agua (DGA)

2007 Informe Final: Estimaciones de Demanda de Agua y Proyecciones Futuras: Zona I Norte Regiones I a IV. Ministerio de Obras Públicas, Santiago.

Dufraisse, Alexa

2012 Firewood and Woodland Management in their Social, Economic and Ecological Dimensions: New Perspectives. In Wood and Charcoal Evidence for Human and Natural History, edited by Ernestina Badal, Yolanda Carrión, Miguel Macías, and Maria Ntinou, pp. 65-74. Saguntum. Departament de Prehistòria i Arqueologia de la Universitat de València, Valencia.

Escola, Patricia, María Gabriela Aguirre, and Salomón Hocsman

2013 La gestión de recursos leñosos por cazadoresrecolectores transicionales en los sectores intermedios de Antofagasta de la Sierra (Catamarca, Argentina): El caso de Alero Sin Cabeza. Revista Chilena de Antropología 27:67-100.

Ewing, Stephanie A., Brad Sutter, Justine Owen, Kunihiko Nishiizumi, Warren Sharp, Steven S. Cliff, Kevin Perry, William Dietrich, Christopher P. McKay, and Ronald Amundson

2006 A Threshold in Soil Formation at Earth's AridHyperarid Transition. Geochimica et Cosmochimica Acta 70(21):5293-5322.

Finstad, Kari, Marco Pfeiffer, and Ronald Amundson

2014 Hyperarid Soils and the Soil Taxonomy. Soil Science Society of America Journal 78(6):1845-1851.

Gajardo, Rodolfo

1994 La vegetación natural de Chile. Editorial Universitaria, Santiago.

Gayo, Eugenia M., Claudio Latorre, Teresa E. Jordan, Peter L. Nester, Sergio A. Estay, Karla F. Ojeda, and Calogero M. Santoro

2012 Late Quaternary Hydrological and Ecological Change in the Hyperarid Core of the Northern Atacama Desert ( $\left.21^{\circ} \mathrm{S}\right)$. Earth Science Reviews 113:120-140.

Gutierrez, Julio R., Francisco Lopez-Cortes, and Pablo A. Marquet

1998 Vegetation in an Altitudinal Gradient along the Rio Loa in the Atacama Desert of Northern Chile. Journal of Arid Environments 40(4):383-399.

Habit, Mario A.

1985 Estado actual del conocimiento sobre Prosopis tamarugo. FAO, Santiago.
Henry, Auréade, Isabelle Théry-Parisot, and Evguenia Voronkova

2009 La gestion du bois de feu en forêt boréale: problématique archéo-anthracologique et étude d'un cas ethnographique (Région de l'Amour, Sibérie). In Fuel Management during the Palaeolithic and Mesolithic Period: New Tools, New Interpretations, edited by Sandrine Costamagno, Isabelle Théry-Parisot, and Auréade Henry, pp. 17-37. BAR International Series 1914, Oxford.

Hoggs, Alan G., Quan Hua, Paul G. Blackwell, Mu Niu, Caitlin E. Buck, Thomas P. Guilderson, Timothy J. Heaton, Jonathan G. Palmer, Paula J. Reimer, Ron W. Reimer, Christian S. M. Turney, and Susan R. H. Zimmerman

2013 SHCal13 Southern Hemisphere Calibration, 0 50,000 Years cal BP. Radiocarbon 55(4):1889_ 1903.

Houston, John

2001 La precipitación torrencial del año 2000 en Quebrada Chacarilla y el cálculo de recarga al acuífero Pampa Tamarugal, norte de Chile. Revista Geologica de Chile 28:163-177.

Japan International Cooperation Agency (JICA)

1995 The Study on the Development of Water Resources in Northern Chile. Japan International Cooperation Agency (Pacific Consultants International), Tokyo.

Joly, Delphine

2008 Etude de la gestion du combustible osseux et végétal dans les stratégies adaptatives des chasseurscueilleurs et des groupes agro-pastoraux d'Argentine durant l'Holocène. Unpublished Ph.D. dissertation, Department of Science de la matière, University of Rennes 1, Rennes.

Joly, Delphine, Ramiro J. March, Dominique Marguerie, and Hugo Yacobaccio

2009 Gestion des combustibles dans la province de Jujuy (Puna, Argentine) depuis l'Holocène ancien: croisement des résultats ethnologiques et anthracologiques. Proceedings of the Gestion des combustibles au paléolithique et au mésolithique: Nouveaux outils, nouvelles interprétations 13:39-52. Lisbon.

Jordan, Teresa Eileen, Naomi E. Kirk-Lawlor, Nicolás Blanco, Jason A. Rech, and Nicolás Cosentino

2014 Landscape Modification in Response to Repeated Onset of Hyperarid Paleoclimate States since $\sim 15 \mathrm{Ma}$, Atacama Desert, Chile. Geological Society of America Bulletin 126(7-8):1016-1046.

Kataki, Rupam, and Dolon Konwer

2001 Fuelwood Characteristics of Some Indigenous Woody Species of North-east India. Biomass and Bioenergy 20:17-23.

Kennett, Douglas J., B. Lynn Ingram, John R. Southon, and Karen Wise

2002 Differences in 14C Age between Stratigraphically Associated Charcoal and Marine Shell from the Archaic Period Site of Kilometer 4, Southern Peru: Old Wood or Old Water? Radiocarbon 44(1):53-58.

Klusek, Marzena, and Sławomira Pawelczyk

2014 Stable Carbon Isotope Analysis of Subfossil Wood from Austrian Alps. Geochronometria 41(4):400-408.

Kolář, Tomas, Michal Rybníček, Marie Střelcová, Josef Hedbávný, and Jan Vít

2014 The Changes in Chemical Composition and Properties of Subfossil Oak Deposited in Holocene Sediments. Wood Research 59(1):149-166. 
Latorre, Claudio, Julio L. Betancourt, and Mary T. K. Arroyo 2006 Late Quaternary Vegetation and Climate History of a Perennial River Canyon in the Río Salado Basin $\left(22^{\circ} \mathrm{S}\right)$ of Northern Chile. Quaternary Research 65:405466.

Latorre, Claudio, Calogero M. Santoro, Paula C. Ugalde, Eugenia M. Gayó, Daniela Osorio, Carolina SalasEgaña, Ricardo De Pol-Holz, Delphine Joly, and Jason A. Rech

2013 Late Pleistocene Human Occupation of the Hyperarid Core in the Atacama Desert, Northern Chile. Quaternary Science Reviews 77:19-30.

Luebert, Federico

2004 Apuntes sobre la vegetación de bosque y matorral del desierto precordillerano de Tarapacá (Chile). Chloris Chilensis 7. Electronic document, http://www.chlorischile.cl/luebertmyrica/imagua.htm, accessed July 27, 2015.

McFadden, Leslie D., Stephen G. Wells, and Michael J. Jercinovich

1987 Influences of Eolian and Pedogenic Processes on the Origin and Evolution of Desert Pavements. Geology 15:504-508.

March, Ramiro J.

1992 L'utilisation du bois dans les foyers préhistoriques: une approche expérimentale. Bulletin de la Société Botanique de France, Actualités Botaniques 139(2/3/4):245-253.

March, Ramiro J., Alexandre Lucquin, Delphine Joly, Juan Carlos Ferreri, and Mohamad Muhieddine

2012 Processes of Formation and Alteration of Archaeological Fire Structures: Complexity Viewed in the Light of Experimental Approaches. Journal of Archaeological Method and Theory 21(1):1-45.

Marconetto, María Bernarda

2010 Paleoenvironment and Anthracology: Determination of Variations in Humidity Based on Anatomical Characters in Archealogical Plant Charcoal (Ambato Valley, Catamarca, Argentina). Journal of Archaeological Science 37:1187-1191.

Marguerie, Dominique, and Jean-Yves Hunot

2007 Charcoal Analysis and Dendrology: Data from Archaeological Sites in North-Western France. Journal of Archaeological Science 34(9):14171433.

Nester, Peter L., Eugenia Gayo, Claudio Latorre, Teresa E. Jordan, and Nicolas Blanco

2007 Perennial Stream Discharge in the Hyperarid Atacama Desert of Northern Chile during the Latest Pleistocene. Proceedings of the National Academy of Sciences of the United States of America 104(50):19724-19729.

Nocus, Noémie

2014 Forêts et sociétés aux étages planitiaires et collinéens de l'alsace du Néolithique au haut Moyen Âge: approche dendro-anthracologique. Unpublished Ph.D. dissertation, Museum d'Histoire Naturelle, Department of Science de la Nature et de l'Homme, Paris.

Piqué i Huerta, Raquel

1999 Produccion y uso del combustible vegetal: Una evaluacion arqueologica. Treballs d'Etnoarqueología 3. Universidad Autónoma de Barcelona, Barcelona.

Placzek, Christa, Jade Quade, Julio L. Betancourt, P. Jonathan Patchett, Jason A. Rech, Claudio Latorre, Ari Matmon, Camile Holmgren, and Nathen B. English
2009 Climate in the Dry Central Andes over Geologic, Millennial, and Interannual Timescales. Annals of the Missouri Botanical Garden 96(3):386397.

Rivero, Diego E.

2012 Human Occupation during the PleistoceneHolocene Transition (from 11,000 to 9000 B.P.) in the Central Highlands of Argentina. Latin American Antiquity 23:551-564.

Rodriguez, M. Fernanda

1999 Movilidad e intercambios durante el Arcaico en la puna argentina. In En los Tres Reinos: Practicas de Recoleccion en el Cono Sur de America, edited by Carlos. A. Aschero, M. Alejandra Korstanje, and Patricia M. Vuoto, pp. 111-119. Magma Publicaciones, San Miguel de Tucuman, Argentina.

2000 Woody Plant Species Used during the Archaic Period in the Southern Argentine Puna: Archaeobotany of Quebrada Seca 3. Journal of Archaeological Science 27:341-361.

2005 Human Evidence from the Mid-Holocene in the Salty Argentine Puna: Analysis of the Archaeobotanical Record. Quaternary International 132:1522.

Santoro, Calogero M., Daniela Osorio, Vivien G. Standen, Paula C. Ugalde, Katherine Herrera, Eugenia M. Gayó, Francisco Rothhammer, and Claudio Latorre

2011 Ocupaciones humanas tempranas y condiciones paleoambientales en el desierto de Atacama durante la transición Pleistoceno-Holoceno. Boletín de Arqueología Pontificia Universidad Católica de Perú 15:120.

Scheel-Ybert, Rita, and Ondemar F. Dias

2007 Corondó: Palaeoenvironmental Reconstruction and Palaeoethnobotanical Considerations in a Probable Locus of Early Plant Cultivation (Southeastern Brazil). Environmental Archaeology 12(2):129138.

Schiffer, Michael B.

1986 Radiocarbon Dating and the "Old Wood" Problem: The Case of the Hohokam Chronology. Journal of Archaeological Science 13(1):13-30.

Schweingruber, Fritz Hans

1990 Anatomy of European Woods: An Atlas for the Identification of European Trees, Shrubs and Dwarf Shrubs. Verlag Paul Haupt, Bern.

Schweingruber, Fritz Hans, Annett Börner, and Ernst Detlef Schulze

2006 Atlas of Woody Plant Stems: Evolution, Structure and Environmental Modifications. Springer, Berlin.

2011 Atlas of Stem Anatomy in Herbs, Shrubs and Trees. Springer, Berlin.

Seijo, María Martín, Raquel Piqué i Huerta, Julia Mayo Torné, Carlos Mayo Torné, and Emilio Abad Vidal

2016 Madera carbonizada en contextos funerarios de la jefatura de Río Grande, Panamá: antracología en el sitio de el Caño. Chungara Revista de Antropología Chilena 48(2):277-294.

Senelwa, Kingiri, and Ralph E. H. Sims

1999 Fuel Characteristics of Short Rotation Forest Biomass. Biomass and Bioenergy 17(2):127-140.

Shackleton, Charlie M., and Frans Prins

1992 Charcoal Analysis and the "Principle of Least Effort"-A Conceptual Model. Journal of Archaeological Science 19(6):631-637. 
Stuiver, Minze, and Paula J. Reimer

1993 Extended 14C Data Base and Revised CALIB 3.014 C Age Calibration Program. Editorial Comment. Radiocarbon 35:215-230.

Sun, Qiang, Thomas L. Rost, and Mark A. Matthews

2006 Pruning-Induced Tylose Develpoment in Stems of Current-Year Shoots of Vitis vinifera (Vitaceae). American Journal of Botany 93(11):15671576.

Taylor, Adam M., Barbara L. Gartner, and Jeffrey J. Morrell 2002 Heartwood Formation and Natural Durability: A Review. Wood and Fibers Science 34:587-611.

Théry-Parisot, Isabelle, and Auréade Henry

2012 Seasoned or Green? Radial Cracks Analysis as a Method for Identifying the Use of Green Wood as Fuel in Archaeological Charcoal. Journal of Archaeological Science 39:381-388.

Thiébault, Stéphanie

1989 Apport de l'analyse anthracologique à la connaissance des combustibles ligneux. In Nature et fonction des foyers préhistoriques, edited by Monique Olive and Yvette Taborin, pp. 81-88. APRAIF, Paris.

Vautherin, Pierre

1995 Le bois de feu: comment le mesurer? Centre Technique du Bois et de l'Ameublement, CTBA, Paris.
Vernet, Jean-Louis

1973 Etude sur l'histoire de la végétation du sud-est de la France au Quaternaire d'après les charbons de bois principalement. Paléobiologie Continentale 4(1):190.

Villagrán, Carolina, Victoria Castro, Gilberto Sánchez, Felipe Hinojosa, and Claudio Latorre

1999 La tradición altiplánica: estudio etnobotánico en los Andes de Iquique, primera región, Chile. Chungara Revista Chilena de Antropologia 31(1):81-186.

White, Robert $\mathrm{H}$.

1987 Effect of Lignin Content and Extractives on the Higher Heating Value of Wood. Wood Fiber Science 19(4):446-452.

Workman, Terry W.

2012 Paleowetlands and Fluvial Geomorphology of Quebrada Maní: Reconstructing Paleo-environments and Human Occupation int the Northern Atacama Desert. Unpublished Master's thesis, Department of Geology \& Environmental Earth Science, Miami University, Oxford, Ohio.

Submitted February 19, 2016; Revised June 29, 2016;

Accepted December 8, 2016 